\title{
Seasonality of sand flies (Diptera: Psychodidae) and Leishmania DNA detection in vector species in an area with endemic visceral leishmaniasis
}

\author{
Lara Saraiva ${ }^{1 /+}$, Camila Gonçalves Leite ${ }^{2}$, Ana Cristina Vianna Mariano da Rocha Lima ${ }^{1}$, \\ Luiz Otávio Alves de Carvalho², Agnes Antônia Sampaio Pereira', Jerônimo Marteleto Nunes Rugani', \\ Felipe Dutra Rego', Célia Maria Ferreira Gontijo', José Dilermando Andrade Filho'
}

${ }^{1}$ Fundação Oswaldo Cruz-Fiocruz, Centro de Pesquisas René Rachou, Grupo de Estudos em Leishmanioses, Belo Horizonte, MG, Brasil ${ }^{2}$ Prefeitura Municipal de Belo Horizonte, Gerência de Controle de Zoonoses, Belo Horizonte, MG, Brasil

BACKGROUND Leishmaniases are a serious health problem in southeast Brazil, including the city of Belo Horizonte (BH), Minas Gerais state $(\mathrm{MG})$, where there are high rates of incidence and mortality due to visceral leishmaniases. BH is divided into nine sanitary districts (SD) of which one, the Venda Nova SD, was selected for this study because it has high rates of positivity for canine leishmaniasis and high incidence of human leishmaniasis.

OBJECTIVES This study aimed to survey the sand fly fauna in Venda Nova SD from August 2011 to July 2013 and perform a descriptive analysis of the vector population.

METHODS The sampling was carried out using automatic HP light traps at all covered areas of the Venda Nova SD, in a total of eighteen light traps. Sampled specimens were identified following Galati (2003), and females were submitted to molecular techniques for the detection and identification of Leishmania DNA. A simple environmental description was done for it area and Kernel estimation was used to infer vector density for each study site.

FINDINGS A total of 2,427 sand fly specimens belonging to eight species and five genera were collected of which $95.3 \%$ were Lutzomyia longipalpis. The seasonal variation curve was delineated by this species. Lu. longipalpis was the most abundant at all collection points and in all months of the study, and exhibited a natural infection rate of $1.01 \%$ for Leishmania infantum and $1.77 \%$ for Leishmania braziliensis.

MAIN CONCLUSIONS The results show the presence and adaptation of Lu. longipalpis to the anthropic environment of BH and reinforces its role as the main vector of $L$. infantum in the region.

Key words: visceral leishmaniasis - Lutzomyia longipalpis - Belo Horizonte

The principal etiological agent of visceral leishmaniases (VL) in the Americas is Leishmania (Leishmania) infantum (Nicolle, 1908) and the main vector of this agent is the sand fly Lutzomyia (Lutzomyia) longipalpis (Lutz \& Neiva, 1912). Distinctively, American cutaneous leishmaniasis (ACL) features a range of etiological agents and sand fly vectors. The clinical presentations, prognoses, epidemiological patterns, and cycles of occurrence vary with the species of parasites involved. Thus, being a multifactorial phenomenon, the species of parasite greatly determines the clinical features of ACL (WHO 2010).

VL has considerable epidemiological importance in Brazil, with an annual rate of incidence between 4,200 to 6,300 cases yearly. The incidence of ACL is much higher ranging from 72,800 to 119,600 cases annually. It should be noted, however, that these incidence are surely underestimates because of the problems that exist with underre-

doi: 10.1590/0074-02760160438

Financial support: CNPq, FAPEMIG.

+ Corresponding author: lara@cpqrr.fiocruz.br

Received 30 September 2016

Accepted 9 December 2016 porting by the public health system in Brazil (Alvar et al. 2012) Furthermore, the areas of epidemiological and public health significance for these diseases are spreading, including urban areas in Brazil. In the southeast of Brazil, the spread of leishmaniasis has been accompanied by a significant increase in the number of cases. The municipality of Belo Horizonte (BH), Minas Gerais (MG) state, and its metropolitan region are one of the most serious examples of the spread of leishmaniasis in southeast Brazil. The first autochthonous VL cases recorded in the city of BH were in 1994. During the subsequent 19 years of the occurrence of the disease the municipality has amassed 1,526 reported cases, with an average annual death rate of $20 \%$ during the past five years (PBH 2014).

The municipality of $\mathrm{BH}$ is divided into nine sanitary districts (SD), each with their own socio-economical, epidemiological and environmental characteristics. Each SD displays their own epidemiological pattern of the number of human VL cases, rate of canine positivity, and composition and seasonal variation of sand fly populations (de Souza et al. 2004, Resende at al. 2006, Saraiva et al. 2011, PBH 2014). Therefore, detailed studies on the sand fly fauna and the epidemiological characteristics of VL in each SD might, together, lead to a better understanding of the occurrence of this disease. Each SD is divided into 


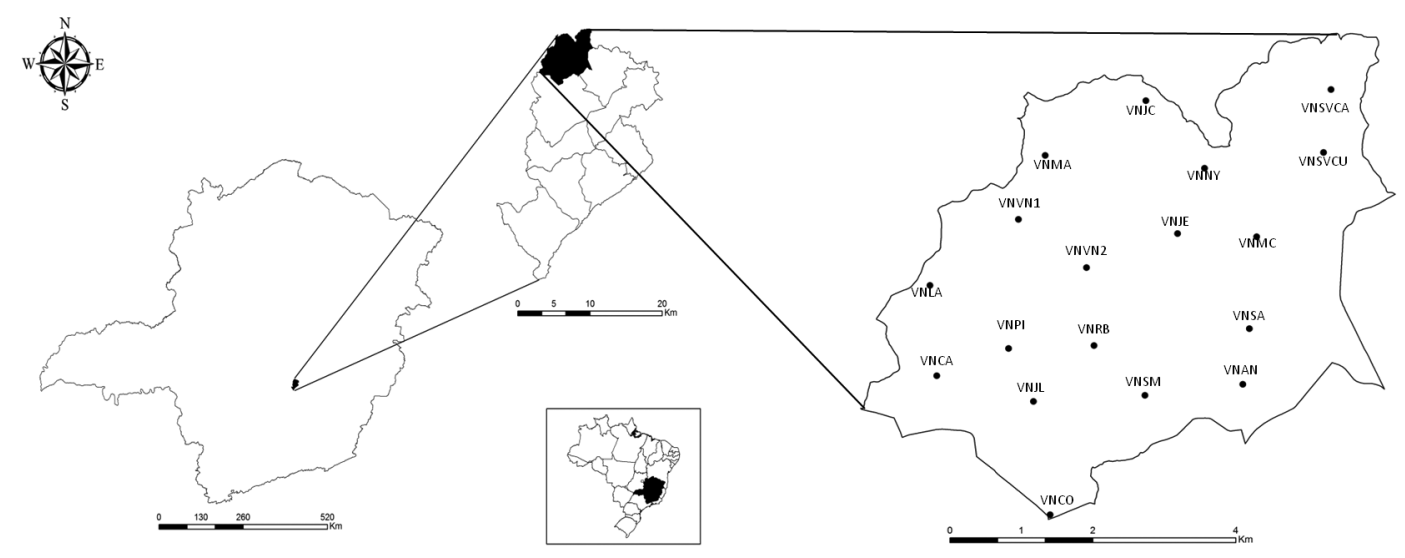

Fig. 1: map showing the location of the city of Belo Horizonte, the Venda Nova Sanitary District, and the local collection points in each coverage area.

coverage areas based on the population assisted at each of the health centres. Studies performed in the metropolitan region of $\mathrm{BH}$ have already documented the sand fly vectors of L. (L.) infantum and Leishmania (Viannia) braziliensis (Vianna, 1911) (Carvalho et al. 2010).

Venda Nova SD, selected for this study, has high rates of positivity for canine leishmaniasis and high incidence of human leishmaniasis. The last sand fly survey carried out in Venda Nova SD occurred from 20012003, and utilised two traps at each of three sampling points in only three coverage areas. The survey found $\mathrm{Lu}$. longipalpis to be the most predominant species, but Nyssomyia intermedia (Lutz \& Neiva, 1912), Nyssomyia whitmani (Antunes \& Coutinho, 1939), Lutzomyia firmatoi (Barretto, Martins \& Pellegrino, 1956) and Evandromyia sallesi (Galvão \& Coutinho, 1939) were also reported, although less abundant (de Souza et al. 2004).

The present study aimed to perform a more detailed survey of sand flies in Venda Nova SD by including all coverage areas and using a simple descriptive methodology but with analysis at the global level, which could be used in the health service of zoonoses control. The detailed knowledge of the seasonal fluctuation curves of the vector species of Leishmania, as well as the knowledge of the areas of greatest occurrence of vector abundance can contribute to the control actions of leishmaniosis control in urban areas. Since the chronic pattern of infection development makes the occurrence of cases an indicator difficult to be used alone.

In this work 18 light traps were used in a single SD of the municipality of $\mathrm{BH}$, in monthly collections of three consecutive days during two years, in the previous studies the quantitative of traps was relatively smaller, as well as the temporal sample effort. De Souza et al. (2004) used 54 traps throughout the municipality with collections of one day, for two years. Resende et al. (2006) used nine traps in three SDs with monthly collections of one day and Saraiva et al. (2011) used 24 traps in only one SD with monthly collections of one day during a sample year.

\section{MATERIALS AND METHODS}

Study area - The Venda Nova SD corresponds to northern portion of the municipality of $\mathrm{BH}$ and was the earliest region of $\mathrm{BH}$ to be developed. It is divided into 16 areas of coverage based on the population assisted at each of the health centres: Andradas (VNAN); Céu Azul (VNCA), Copacabana (VNCO), Jardim dos Comerciários (VNJC), Jardim Europa (VNJE), Jardim Leblon (VNJL), Lagoa (VNLA), Mantiqueira (VNMA), Minas Caixa (VNMC), Nova Yorque (VNNY), Piratininga (VNPI), Rio Branco (VNRB), Santo Antônio (VNSA), Santa Mônica (VNSM), Serra Verde (VNSVCU and VNSVCA) and Venda Nova (VNVN1 and VNVN2) (PBH 2014) (Fig. 1).

Sand fly collection - Procedures for collecting sand flies were approved by the Ministério do Meio Ambiente do Brasil (Ministry of Environment of Brazil) - (SISBIO license number 15,237). For the analysis of sand fly populations, 18 light traps were arranged uniformly within the SD; one trap was centrally located in each health centre coverage area. In two sites, Serra Verde (VNSV) and Venda Nova (VNVN), two traps were used because the geographical areas of these sites did not enable the location of a single central point. A simple environmental characterisation was performed at each collection point by recording environmental characteristics related to phlebotomine occurrence at a locality. These characteristics included the presence of vegetation and the presence of water, both of which relate to breeding sites and the supportive environment for phlebotomine. The presence of livestock, the presence of a hen house, and the presence of a dog kennel are all related to providing a source of food for females. The traps when possible were placed inside the shelters of the animals, or as close as possible to the environments of interest, a few metres away, at most about 10 metres. The environmental characteristics of the collection point are briefly described in (Table I).

Traps were randomly distributed, thus allowing the assessment of locations as either favorable or not for the development and collection of sand flies. The principle aim trapping was the uniformity of the sample effort in geographical area (Table I).

Sampling was carried out by endemic disease control agents and were integrated with the regular activities of Zoonoses Control in Venda Nova SD. The sampling period was from August 2011 to July 2013, with a total sam- 


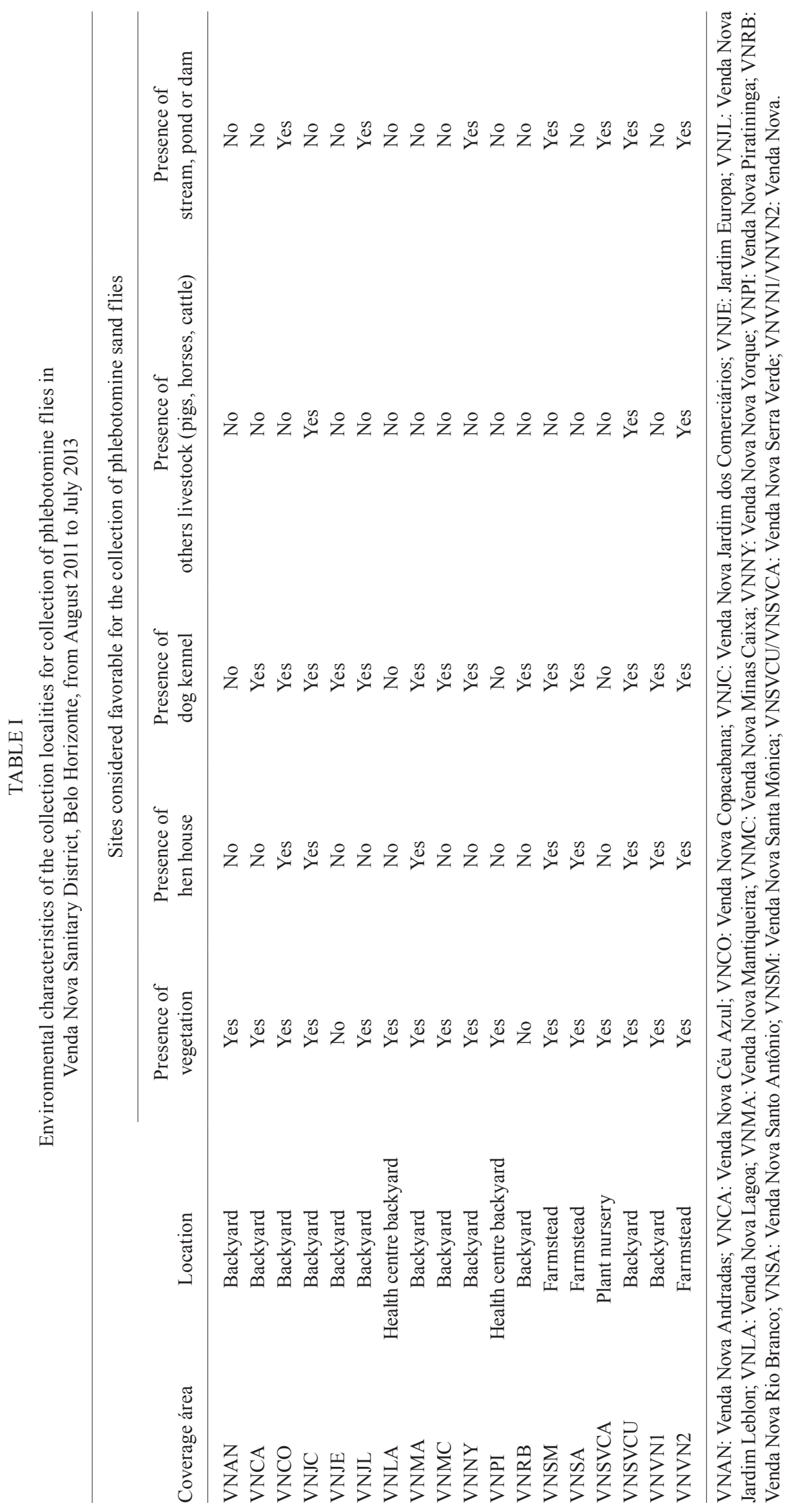


pling effort of 31,104 hours. Phlebotomine collections were performed with automatic HP traps (Pugedo et al. 2005) in $12 \mathrm{~h}$ nocturnal collections of three consecutive days, performed monthly for two years. In fixed weeks, always in the third week of each month. The classification proposed by Galati (2003) was used to identify the specimens. Females of Ev. sallesi and Ev. cortelezzii (Brethes, 1923) were recorded as belonging to the "cortelezzii complex" when morphological differentiation was inconclusive.

Detection of Leishmania DNA in trapped females Trapped females were stored in DMSO 6\% until DNA extraction using the Puregene ${ }^{\circledR}$ QIAGEN Gentra kit. All samples were analysed individually and Polymerase chain reaction (PCR) for the molecular target internal transcribed spacer I (ITS-1) (Schönian et al. 2003) and the small subunit (SSU) (Cruz et al. 2002) were performed following the methodology modified by (Rego et al. 2014).

The positive controls were DNA of four reference strains: L. braziliensis (MHOM/BR/75/M2903), L. guyanensis (MHOM/BR/75/M4147), L. infantum (MHOM/ $\mathrm{BR} / 74 / \mathrm{PP} 75$ ), and L. amazonensis (IFLA/BR/67/PH8) at a concentration of $20 \mathrm{ng} / \mathrm{mL}$. For species identification the amplified products of the ITS-1 reactions were digested by the enzyme Hae III as described by Schöniam et al. (2003).

If the restriction fragment analysis did not produce visible DNA bands, the whole fragment resulting from the PCR amplification of the ITS-1 or SSU region was sequenced. To purify the product QIAquick ${ }^{\circledR}$ PCR Purification Kit (Qiagen) was used following the manufacturer's instructions. Next, a mixture was prepared containing $1 \mu \mathrm{L}$ of purified products, $1 \mu \mathrm{L}$ of each primer at a concentration of $5 \mathrm{pmol}$, antisense or sense (in separate tubes), $1 \mu \mathrm{L} 5 \mathrm{x}$ Sequencing Buffer, $1 \mu \mathrm{L}$ of BigDye ${ }^{\circledR}$ Terminator v3.1 Cycle Sequencing, and distilled water for a final volume of $10 \mu \mathrm{L}$. The program used $35 \mathrm{cy}-$ cles alternating between $95^{\circ} \mathrm{C}$ for $15 \mathrm{~s}$ and $65^{\circ} \mathrm{C}$ for $15 \mathrm{~s}$. The ITS-1 fragment sequences were read using an ABI 3730xl DNA Analyser automatic DNA sequencer.

Analyses - All data were analysed descriptively using Microsft Excel software and statistical analyses were performed using the program Graph Pad Prism. The ecological indices of richness, diversity and equitability were calculated using PAST software.

The entomological sampling sites were georeferenced using GPS - GARMIN eTrex-H for spatial analysis of population density of suspected and confirmed vector species. Coordinates and presence/absence data of vectors in each site were analysed using ArcGIS 9.3 software.

Kernel estimation was used to infer vector density for each study site. This is a nonparametric statistical method of interpolation that identifies sites with the highest occurrence of a given event (MS 2007). In the present study, sand fly species were categorised as vector (suspected or confirmed) and non-vector species Leishmania sp.

Climatological data were obtained from the Ministério da Agricultura e Abastecimento, Instituto Nacional de Meteorologia (Ministry of Agriculture and Supply, National Institute of Meteorology).

\section{RESULTS}

Sand fly fauna - A total of 2,427 sand flies of eight species belong to five genera were collected. The ratio of males to females was 4.26:1. The species with the highest abundance was Lu. longipalpis $(2,313)$, representing $95.30 \%$ of the specimens collected, followed by Ev. cortelezzii $(1.52 \%)$, Ev. sallessi $(0.66 \%)$, and $N y$. whitmani $(0.37 \%)$ (Table II).

Differences among the coverage areas in the abundance of specimens collected were due to the number of Lu. longipalpis specimens. One location, VNSVCA, had no phlebotomine specimens collected, whereas all the other locations had at least two individuals of two species collected. In the first year of sampling, the greatest numbers of sand flies were collected during the months of August, January and April, whereas the cold and dry months had the lowest numbers. The second year had lower abundances of collected sandflies as a general pattern. The months with the greatest numbers of sand flies collected were October, December and March. Analyses of the seasonal curve with climatic parameters showed that peaks of sand fly abundance coincided with, or followed, periods of high rainfall; a similar pattern was observed for relative humidity. Higher temperatures also coincided with peaks of sand fly occurrence (Fig. 2). However, in spite of these apparent correlations, none of the climatic parameters showed a statistically significant correlation with the seasonal curve of sand flies in Venda Nova SD [Temperature - $(p=0.1052$ - Pearson correlation test $)$, Precipitation - $(p=0.3798$ - Spearman correlation test), Air relative humidity $(\mathrm{p}=0.8506$ - Pearson correlation test)].

The seasonal pattern of occurrence of $L u$. longipalpis varied remarkably between years and among the coverage areas. In the first year of sampling (August 2011 to July 2012), Lu. longipalpis had the highest abundance and VNSM was the locality with the highest relative abundance with $71.53 \%$ of the specimens collected. The total collection curve for this time period was largely determined by specimens collected from VNSM and VNJE, which accounted for $11.53 \%$ of the total specimens collected. In the second year of sampling VNSA was the coverage area with the highest percentage of collected specimens at $68.84 \%$, while VNSM accounted for only $2.12 \%$ (Table II, Fig. 2).

The species accumulation curve analysis for Venda Nova SD reached saturation at the 19th sampling event with only eight species. These data, combined with the seasonal pattern, demonstrate the dominance of $\mathrm{Lu}$. longipalpis in the urban environment. In Venda Nova SD, the species seasonal variation curve was determined by Lu. longipalpis (Fig. 2, Table III).

Margalef diversity and Equitability $\mathrm{J}$ indices adequately described the sand fly communities in Venda Nova SD. Low species diversity and the marked dominance of $L u$. longipalpis are reflected in the low values for these indices over the sampling period (Table III).

The distribution of sand flies in the urban environment is unequal with respect to the abundance of specimens collected; a greater number of specimens were collected in areas with more attractive environmental 


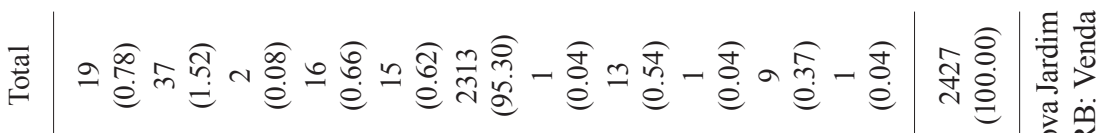

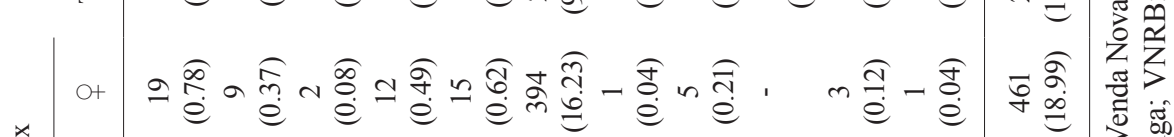

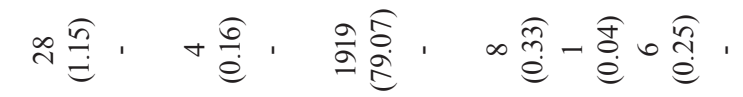

: $\stackrel{\widehat{\sigma}}{\stackrel{\dot{\alpha}}{\infty}}$

穹要

글 $(1+\sin$

$\left|\begin{array}{l}z \\ z\end{array}\right|$

n

$\circ \circ$

ㄱ.

$\circ$

$\circ 00$

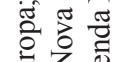$$
-
$$$$
\text { ( }
$$$$
0000
$$$$
\text { in } 00000
$$$$
\stackrel{n}{n} \circ \infty 00
$$

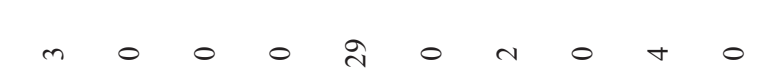




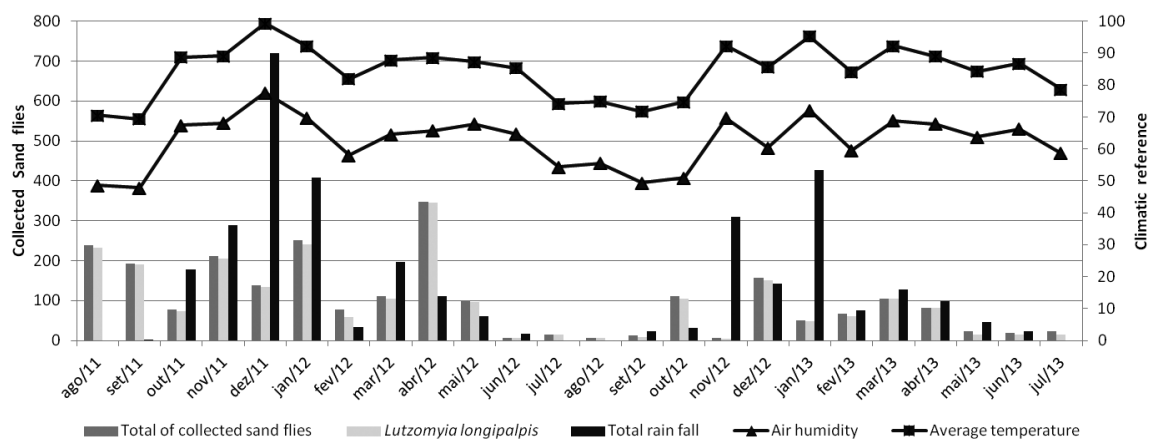

Fig. 2: seasonal variation of sand flies and climate parameters of total precipitation, relative humidity and mean temperature in Venda Nova Sanitary District from August 2011 to July 2013.

TABLE III

Margalef diversity and equitability J indices by sampling event in Venda Nova Sanitary District, from August 2011 to July 2013

\begin{tabular}{|c|c|c|c|c|c|c|c|c|c|c|c|c|}
\hline \multirow[b]{2}{*}{ Sampling } & \multicolumn{12}{|c|}{ First year } \\
\hline & $1^{\mathrm{o}}$ & $2^{\circ}$ & $3^{\circ}$ & $4^{\mathrm{o}}$ & $5^{\mathrm{o}}$ & $6^{\mathrm{o}}$ & $7^{\circ}$ & $8^{\circ}$ & $9^{\circ}$ & $10^{\circ}$ & $11^{\circ}$ & $12^{\circ}$ \\
\hline Richness & 2 & 3 & 3 & 3 & 4 & 4 & 3 & 3 & 2 & 2 & 1 & 1 \\
\hline Species accumulation & 2 & 3 & 4 & 5 & 5 & 5 & 5 & 6 & 6 & 6 & 6 & 6 \\
\hline Margalef diversity & 0.18 & 0.38 & 0.46 & 0.37 & 0.61 & 0.55 & 0.48 & 0.43 & 0.17 & 0.22 & 0.00 & 0.00 \\
\hline \multirow[t]{2}{*}{ Equitability_J } & 0.15 & 0.08 & 0.22 & 0.14 & 0.12 & 0.09 & 0.25 & 0.13 & 0.03 & 0.08 & 0.00 & 0.00 \\
\hline & \multicolumn{12}{|c|}{ Second year } \\
\hline Sampling & $13^{\circ}$ & $14^{\mathrm{o}}$ & $15^{\circ}$ & $16^{\circ}$ & $17^{\mathrm{o}}$ & $18^{\circ}$ & $19^{\circ}$ & $20^{\circ}$ & $21^{\circ}$ & $22^{\circ}$ & $23^{\circ}$ & $24^{\circ}$ \\
\hline Richness & 1 & 3 & 2 & 1 & 2 & 1 & 3 & 1 & 1 & 3 & 2 & 3 \\
\hline Species accumulation & 6 & 7 & 7 & 7 & 7 & 7 & 8 & 8 & 8 & 8 & 8 & 8 \\
\hline Margalef diversity & 0.00 & 0.87 & 0.21 & 0.00 & 0.20 & 0.00 & 0.48 & 0.00 & 0.00 & 0.63 & 0.36 & 0.68 \\
\hline Equitability_J & 0.00 & 0.58 & 0.30 & 0.00 & 0.17 & 0.00 & 0.24 & 0.00 & 0.00 & 0.72 & 0.34 & 0.64 \\
\hline
\end{tabular}

characteristics, as was the case with VNSM. However, there are some locations with environmental characteristics considered highly attractive but had a low percentage of the total specimens collected, as was the case with VNSVCU. Lu. longipalpis was collected in 15 of the 16 study localities in Venda Nova SD and was the most abundant species in these 15 locations (Tables I-II).

The distribution maps of vector and probable-vector species indicate a concerning epidemiological situation in all coverage areas. Throughout Venda Nova SD and three specific coverage areas (VNSM, VNSA and VNJE) $\mathrm{Lu}$. longipalpis had a high spatial accumulation. In this analysis, the map of vector occurrence can be used to evaluate the map of occurrence of $\mathrm{Lu}$. longipalpis given the high abundance of this species in the SD (Fig. 3).

Leishmania DNA detection in female sand flies - Of the 461 females collected in the Venda Nova SD, 12 had positive amplifications for intergenic region ITS-1. Two samples were also submitted to the SSU-RNA target reaction and had positive results. All positive samples were of
Lu. longipalpis. Four of the samples identified the presence of L. infantum DNA, seven identified L. braziliensis DNA, and one sample could only be characterised as belonging to the family Tripanossomatidae, this sample was positive only for ITS-1 reaction (Table IV).

Just three coverage areas, VNSM, VNMC and VNJE, had specimens that were positive for Leishmania DNA. VNMC had three positive specimens and VNSM had four positive specimens and VNJE had five. In VNMC only L. braziliensis was identified, in VNSM and VNJE both $L$. braziliensis and $L$. infantum were found. The total natural infection rate in the SD was $2.38 \%$. The overall infection rate for $L u$. longipalpis was $2.79 \%$, with $L$. infantum and L. braziliensis having infection rates of $1.01 \%$ and $1.77 \%$, respectively.

\section{DISCUSSION}

Considering how long humans have been on the planet, urbanisation is a very recent phenomenon and understanding its effects on human health remains a major challenge for public health. This perspective becomes 


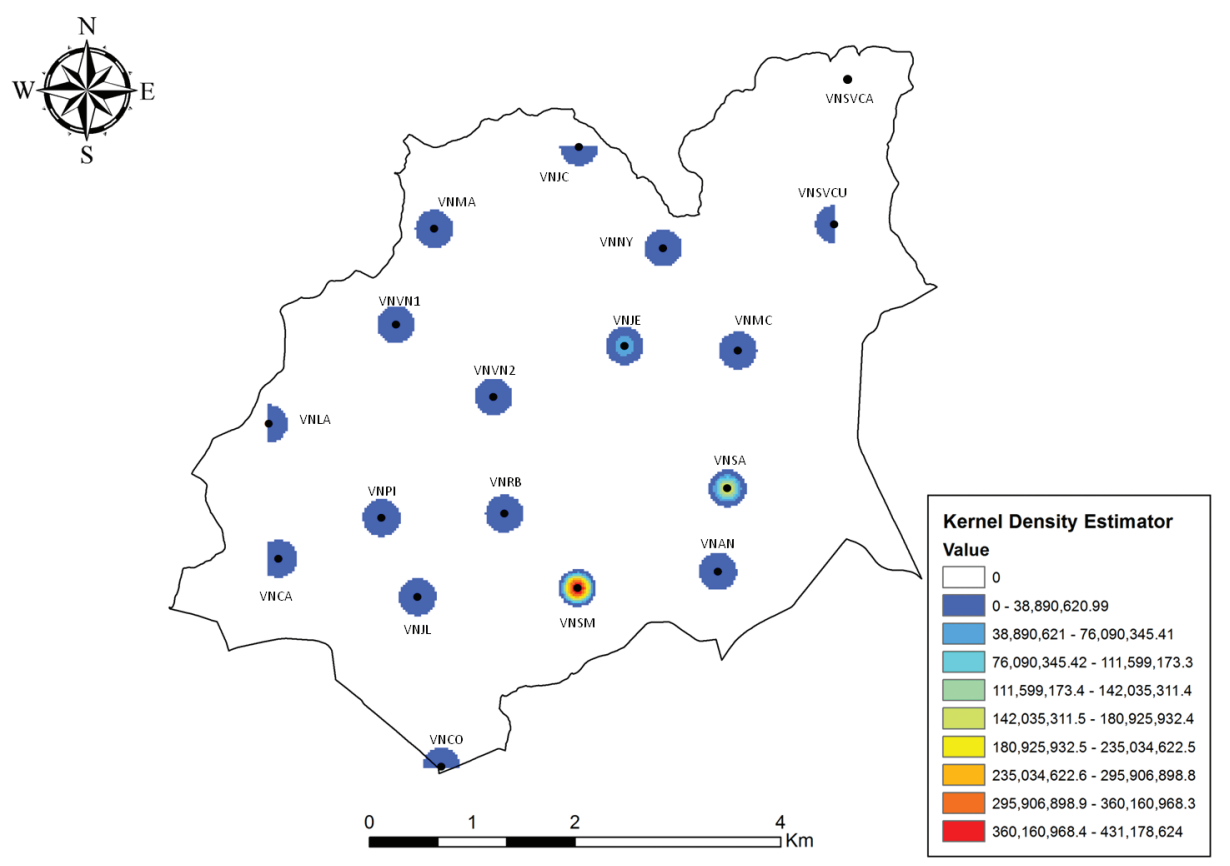

Fig. 3: map showing the Venda Nova Sanitary District and the Kernel density analysis of vectors.

even more dramatic when one considers urbanisation in underdeveloped countries in the tropics (Lau et al. 2010).

The current epidemiological importance of VL in large Brazilian cities illustrates this challenge. Despite the great number of studies on various aspects of this disease and the implementation of control measures, human and canine infections remain a serious problem (MS 2006).

In addition, performing reliable evaluations of the impact of control measures in epidemiological scenarios where the disease is occurring remains problematic. A number of factors may influence the quality of control measures but there is no standardized procedure to evaluate the quality of the actions that are implemented (MS 2006). Complex statistical models already used for epidemiological description of leishmaniasis are beyond the objectives of this study (Araújo et al. 2013). The study was developed with a methodology that could be reproduced in the field of health services in Brazilian municipalities.

Venda Nova SD is located in the northern portion of the city of $\mathrm{BH}$ and is a mosaic of urbanisation, slums, urban agglomerations, and areas with markedly rural characteristics. In this study, the simple environmental characterisation that was performed demonstrates that urban organisation might create environments that favor the occurrence of certain synanthropic species involved in disease cycles that represent risks to human health.

From the 18 sand-fly collection localities, eight had hen houses, three had other animals such as cattle, horses and pigs, and fourteen had dogs. Inadequate management of hen houses can favor the presence of animals that could represent a risk to human, such as phlebotomines and rodents (Lainson \& Rangel 2005). The domestic dog is recognised as the main urban reservoir of $L$. infatum in Brazil, and their role as a reservoir for L. brazileinzis needs to be clarified (Marzochi \& Marzochi 2004).

Breeding certain animals, such as pigs, cattle and horses, in urban areas is not prohibited by the health code of the city of $\mathrm{BH}$, however, such species bred inappropriately might favor the occurrence of an unhealthy environment that favors the development of urban health problems. Thus, according to the health code, it is expected that citizens act responsibly with their property and should prevent conditions that favor the occurrence of synanthropic animals and other environmental conditions that can represent a health risk to the community $(\mathrm{PBH}$ 2014). For example, in the three places where there were livestock animals breeding, there was an accumulation of feces, for which there was inadequate treatment facilities.

Only two of the collection sites had no vegetation present, but seven collection sites were close to bodies of water. Phlebotomines typically are associated with locations possessing vegetation, decomposing organic matter, moisture and shaded locations. Consideration of environmental characteristics is critical for planning improved measures for Leishmaniasis control. The importance of environmental characteristics in transmission foci has been considered in several studies (Teodoro et al. 2004). Environmental characterisation and management strategies need to be incorporated in any VL control programs (WHO 2010)

The 2,427 specimens collected in the Venda Nova SD were allocated to only eight species, and of these, $95.3 \%$ were $L u$. longipalpis. This species was collected in 15 of the 16 coverage areas sampled in the urban area and was the most abundant in all 15. These findings support the suggestion that urbanization be regarded as a risk factor for the occurrence of the transmission cycle of $L$. infantum in areas of the Brazilian Cerrado, particularly 
when natural processes are disrupted by anthropogenic disturbance (Cattand et al. 2006).

Although in low abundance, suspected or proven vectors of $L$. braziliensis were among the species collected at Venda Nova SD. Ny. whitmani, an important vector of L. braziliensis (Rangel \& Lainson 2009), was recorded and represented $0.37 \%$ of the total sample collected in Venda Nova SD. The possibility of $N y$. whitmani participating in the transmission cycles of $L$. infantum needs to be clarified (Margonari et al. 2010, Saraiva et al. 2010).

Specimens of Ev. sallesi and Ev. cortelezzii, as well as the cortelezzii complex, were also recorded in low abundance in Venda Nova SD, totaling less than 3\% of all the phlebotomines collected. Species of the cortelezzii complex are suspected of participation in the transmission of $L$. braziliensis and $L$. infantum to humans (Nascimento et al. 2013).

$E v$. lenti had a low abundance with only two specimens being collected. This species is frequently collected in areas of Leishmania transmission and L. braziliensis DNA was detected in this species in a study conducted in the state of MG (Margonari et al. 2010). This species can be used as an index species for the occurrence of $L u$. longipalpis (Pinto et al. 2012).

Only one specimen each of Sciopemyia Sordellii (Shannon \& Del Ponte, 1927), Micropygomyia scheberi (Martins, Falcão \& Silva, 1975) and Lu. carvernicola (Costa Lima, 1932) were collected. These records are surprising because these species are not known to exhibit synanthropic behavior and are not commonly reported in urban areas (Pinheiro et al. 2013). One possible explanation is trap contamination, but this is highly unlikely because the traps used were used only in Venda Nova SD. Lu. cavernicola and Sc. sordelli are associated with cave environments, but the former species has also been recorded in other ecotypes such as forests and pastures (Carvalho et al. 2010, Rego et al. 2014). There is no evidence that these species participates in the transmission cycles of Leishmania sp. Likewise, there is no evidence that Mi. schreiberi participates in the transmission cycle of leishmanniasis. The single specimen of $M i$. schreiberi collected in Venda Nova SD was recorded in a cattle shed (VNSVCU), which is consistent with other findings about this species (Souza et al. 2009).

The ecological characteristics of the sand fly fauna of Venda Nova SD, low species richness, diversity, evenness and the expressive dominance of $L u$. longipalpis. show how anthropogenic influences may result in increased exposure of human populations to sand fly vectors and, as a consequence, an increased risk of being infected by Leishmania (Cattand et al. 2006). The species accumulation curve of Venda Nova SD stabilised late (at the 19th sampling event) and with low species richness even though there was a great sampling effort. This urban area also had a considerably low level of evenness, which helps to explain these characteristics of the species accumulation curve.

Epidemiological data for Venda Nova SD, and the pattern of Lu. longipalpis occurrence reinforces the statement that this species is the main vector of $L$. infantum in Brazil. Since the 1960's several studies have indicated morphological differences among populations of this spe- cies and recently there have been studies that indicate that $\mathrm{Lu}$. longipalpis is a complex of species varying in morphological, genetic and behavioral characteristics (Mangabeira \& Herlock 1961, Bauzer et al. 2002). In previous studies of sand flies in $\mathrm{BH}, \mathrm{Lu}$. longipalpis was found to have anthropophilic tendencies, with high abundances and high rates of natural infection. The data presented herein corroborate other studies that have demonstrated that $L u$. longipalpis has a great ability to adapt to an anthropogenically modified environment and that it tends to be the most abundant species in the urban areas where it occurs (Oliveira et al. 2003, de Souza et al. 2004).

$\mathrm{Lu}$. longipalpis was the dominant species in every area where sand flies were collected and in every month of the study. The species has been recorded both in locations with a high number of environmental characteristics favorable to the occurrence of phlebotomines, and in locations that did not have many of these characteristics.

The pattern of the seasonal curve of sand flies in Venda Nova SD is strongly determined by Lu. longipalpis. The peaks in phlebotomine collection match the warmer and wetter periods. Absence of statistically significant correlation between the seasonal curve and climatic factors may indicate the need for more a detailed evaluation of the climatic parameters. Studies indicate that the use of weekly evaluations and the local collection of climate data are preferred (Rego et al. 2014). Unfortunately, local climate data were not collected in the present study and weekly data were not available. Interestingly, the pattern of seasonal variation in phlebotomines in this study differs from other studies conducted in BH (de Souza et al. 2004). These data demonstrate that the surveillance and control of the leishmaniasis needs to have constant, or periodic, sand fly population monitoring.

The natural infection rates of $L u$. longipalpis by $L$. infatum and L. braziliensis agree with the epidemiological scenario of serological positivity in dogs of the SD (Margonari et al. 2006, PBH 2014). The possibility of $L u$. longipalpis acting as a vector of $L$. braziliensis requires further study. Lu. longipalpis is permissive to the development of various Leishmania species in laboratory (Walters et al. 1993).

The interpretation of the data presented in Table IV makes clear the difficulty of obtaining satisfactory identification of leishmanial DNA from material extracted from phlebotomine. Even with the low quality of the data, they were presented as being consistent with the epidemiological situation of the SD.

Currently, geoprocessing tools have been used extensively in studies of disease occurrence and associated factors (Margonari et al. 2006, Araújo et al. 2013). In a study conducted throughout the city of $\mathrm{BH}$ from 2001 to 2002, spatial correlation was found among the greater abundance of sand flies, the greater occurrence of human cases of LVH, and the greater occurrence of Leishmania seropositive dogs (Margonari et al. 2006). The descriptive vector density map and the analysis of Leshmania DNA detection indicate that VNSM, VNJE, VNSA and VNMC are the areas with the highest risks when considering the variables related to vectors. 


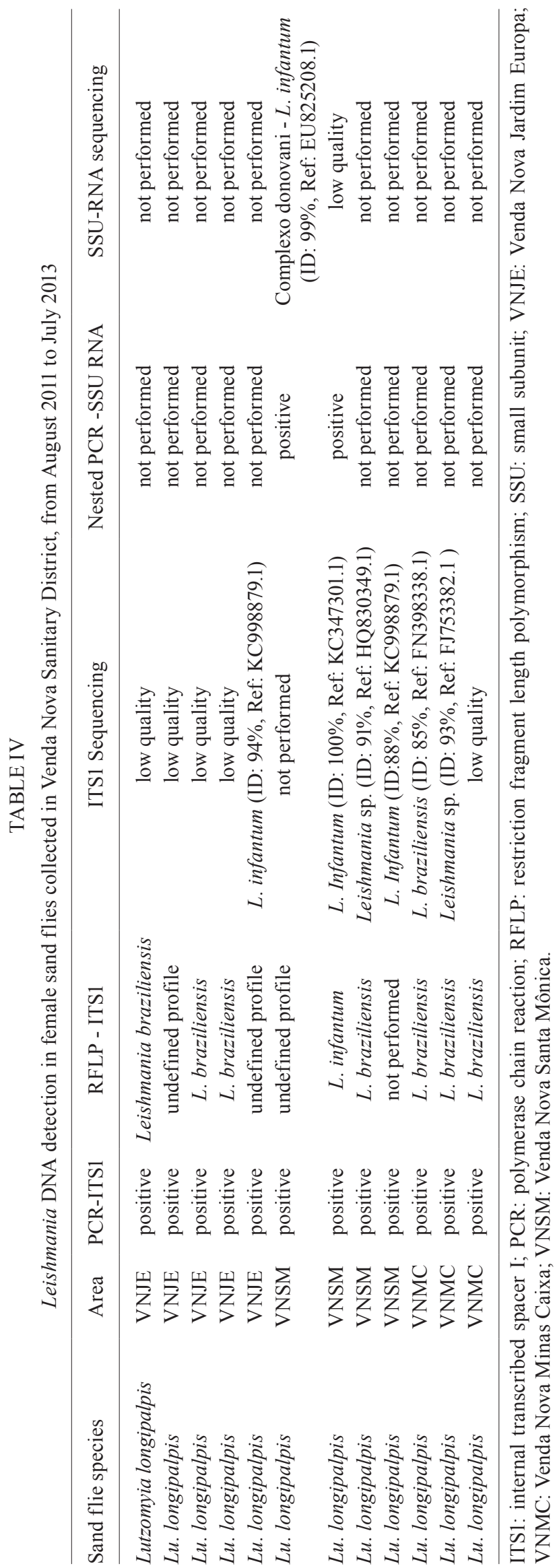

The numerous previous studies on the sand fly fauna of the city of BH have had different sampling strategies, were performed in different locations, and had different results (de Souza et al. 2004, Resende et al. 2006, Saraiva et al. 2011). The present work is the most detailed survey of the sand fly fauna of a SD to date, and it demonstrates the amount of variation that exists in species richness, species abundance, and natural infection rates among the sampled areas and among the studied time periods. Furthermore, it demonstrates the necessity of introducing a systematic monitoring of sand flies in order to evaluate LV control strategies, particularly concerning the chemical control of its vectors.

\section{ACKNOWLEDGEMENTS}

To the community of "Sanitary District of Venda Nova" and the team of Zoonoses workers to the collaboration in the field sampling process; Fiocruz, for the technical and logistic support, and Prefeitura Municipal de Belo Horizonte, Minas Gerais (MG), Brazil.

\section{AUTHORS' CONTRIBUTION}

LS - Elaboration and planning of the project, fieldwork, preparation and identification of sand flies, perform molecular techniques, results analysis, final writing of the article; CGL - elaboration and planning of the project, fieldwork; ACVMRL, AASP and JMNR - perform molecular techniques and results analysis; LOAC - elaboration and planning of the project, fieldwork; FDR - perform spatial techniques and results analysis; CMFG - elaboration and planning of the project, results analysis, final writing of the article; JDAF - elaboration and planning of the project, identification of sand flies, final writing of the article.

\section{REFERENCES}

Alvar J, Velez ID, Bern C, Herrero M, Desjeux P, Cano J, et al. Leishmaniasis worldwide and global estimates of its incidence. PLoS ONE. 2012; 7(5): e35671.

Araújo VEM, Pinheiro LC, Almeida MCDM, de Menezes FC, Morais MHF, Reis IA, et al. Relative risk of visceral leishmaniasis in Brazil: a spatial analysis in urban area. PLoS Negl Trop Dis. 2013; 7(11): e2540.

Bauzer LG, Gesto JS, Souza NA, Ward RD, Hamilton JG, Kyriacou $\mathrm{CP}$, et al. Molecular divergence in the period gene between two putative sympatric species of the Lutzomyia longipalpis complex. Mol Biol Evol. 2002; 19(9): 1624-7.

Carvalho GM, Gontijo CM, Falcão AL, Andrade Filho JD. Study of phlebotomine sand flies (Diptera: Psychodidae) collected in a leishmania-endemic area of the metropolitan region of Belo Horizonte, Brazil. J Med Entomol. 2010; 47(6): 972-6.

Cattand P, Desjeux P, Guzman MG, Jannin J, Kroeger A, Medici A, et al. Tropical diseases lacking adequate control measures: dengue, leishmaniasis, and African Trypanosomiasis. In: Jamison DT, Breman JG, Measham AR, Alleyne G, Claeson M, Evans DB, et al., editors. Diseases control priorities in developing countries. Washington (DC); 2006.

Cruz I, Cañavate C, Rubio JM, Morales MA, Chicharro C, Laguna F, et al. A nested polymerase chain reaction (Ln-PCR) for diagnosing and monitoring Leishmania infantum infection in patients coinfected with human immunodeficiency virus. Trans R Soc Trop Med Hyg. 2002; 96(Suppl. 1): 185-9. 
de Souza CM, Pessanha JE, Barata RA, Monteiro EM, Costa DC, Dias ES. Study on phlebotomine sand fly (Diptera: Psychodidae) fauna in Belo Horizonte, state of Minas Gerais, Brazil. Mem Inst Oswaldo Cruz. 2004; 99(8): 795-803.

Galati EAB. Classificação de Phlebominae. In: Rangel EF, Lainson R, editors. Flebotomíneos do Brasil. Rio de Janeiro: Fiocruz; 2003. pp. 23-52.

Lainson R, Rangel EF. Lutzomyia longipalpis and the eco-epidemiology of American visceral leishmaniasis, with particular reference to Brazil - A Review. Mem Inst Oswaldo Cruz. 2005; 100(8): 811-27.

Lau CL, Smythe LD, Craig SB, Weinstein P. Climate change, flooding, urbanisation and leptospirosis: fuelling the fire? Trans R Soc Trop Med Hyg. 2010; 104(10): 631-8.

Mangabeira O, Herlock IA. Description of 4 new species of phlebotominae of Bahia (Diptera, Psychodidae). Rev Bras Biol. 1961; 21: 265-76.

Margonari C, Freitas CR, Ribeiro RC, Moura ACM, Timbó M, Gripp $\mathrm{AH}$, et al. Epidemiology of visceral leishmaniasis through spatial analysis, in Belo Horizonte municipality, state of Minas Gerais, Brazil. Mem Inst Oswaldo Cruz. 2006; 101(1): 31-8.

Margonari C, Soares RP, Andrade-Filho JD, Xavier DC, Saraiva L, Fonseca AL, et al. Phlebotomine sand flies (Diptera: Psychodidae) and Leishmania infection in Gafanhoto Park, Divinópolis, Brazil. J Med Entomol. 2010; 47(6): 1212-9.

Marzochi MCA, Marzochi KB. Tegumentary and visceral leishmaniases in Brazil: emerging anthropozoonosis and possibilities for their control. Cad Saude Publica. 1994; 10(Suppl. 2): 359-75.

MS - Ministério da Saúde. Introdução à estatística espacial para saúde pública. Brasília: 2007. Available from: http://www.escoladesaude. pr.gov.br/arquivos/File/TEXTOS_CURSO_VIGILANCIA/capacitacao_e_atualizacao_em_geoprocessamento_em_saude_3.pdf.

MS - Ministério da Saúde. Manual de vigilância e controle da leishmaniose visceral. 2006. Available from: http://bvsms.saude.gov. br/bvs/publicacoes/manual_vigilancia_controle_leishmaniose_ visceral.pdf.

Nascimento BW, Saraiva L, Neto RG, Meira PC, Sanguinette CC, Tonelli GB, et al. Study of sand flies (Diptera: Psychodidae) in visceral and cutaneous leishmaniasis areas in the central-western state of Minas Gerais, Brazil. Acta Trop. 2013; 125(3): 262-8.

Oliveira AG, Andrade Filho JD, Falcão AL, Brazil RP. Study of sand flies (Diptera, Psychodidae, Phlebotominae) in the urban area of Campo Grande, Mato Grosso do Sul state, Brazil, from 1999 to 2000. Cad Saude Publica. 2003; 19(4): 933-44.

PBH - Prefeitura Municipal de Belo Horizonte - Secretaria Municipal de Saúde de Belo Horizonte. LEI 7.031, de 12 de janeiro de 1996. 2014. Available from: www.cmbh.mg.gov.br/sites/default/.../codigo_sanitario_-_lei_7031.doc.

Pinheiro MP, Silva JH, Cavalcanti KB, Azevedo PR, Ximenes MFM. Ecological interactions among phlebotomines (Diptera: Psy- chodidae) in an agroforestry environment of northeast Brazil. J Vector Ecol. 2013; 38(2): 307-16.

Pinto IS, Ferreira AL, Valim V, Carvalho FS, Silva GM, Falcão AL, et al. Sand fly vectors (Diptera, Psychodidae) of American visceral leishmaniasis areas in the Atlantic Forest, state of Espírito Santo, southeastern Brazil. J Vector Ecol. 2012; 37(1): 90-6.

Pugedo H, Barata RA, Franca-Silva JC, Silva JC, Dias ES. HP: an improved model of suction light trap for the capture of small insects. Rev Soc Bras Med Trop. 2005; 38(1): 70-2.

Rangel EF, Lainson R. Proven and putative vectors of American cutaneous leishmaniasis in Brazil: aspects of their biology and vectorial competence. Mem Inst Oswaldo Cruz. 2009; 104(7): 937-54.

Rego FD, Shimabukuro PH, Quaresma PF, Coelho IR, Tonelli GB, Silva KM, et al. Ecological aspects of the Phlebotominae fauna (Diptera: Psychodidae) in the Xakriaba Indigenous Reserve, Brazil. Parasit Vectors. 2014; 7: 220.

Resende MC, Cristina M, Camargo V, Marinho JR, Celi R, Nobi A, et al. Seasonal variation of Lutzomyia longipalpis in Belo Horizonte, state of Minas Gerais. Rev Soc Bras Med Trop. 2006; 39(1): 51-5.

Saraiva L, Andrade Filho JD, Falcão AL, de Carvalho DA, de Souza CM, Freitas CR, et al. Phlebotominae fauna (Diptera: Psychodidae) in an urban district of Belo Horizonte, Brazil, endemic for visceral leishmaniasis: characterization of favored locations as determined by spatial analysis. Acta Trop. 2011; 117(2): 137-45.

Saraiva L, Andrade Filho JD, Silva SO, de Andrade ASR, Melo MN. The molecular detection of different Leishmania species within sand flies from a cutaneous and visceral leishmaniasis sympatric area in Southeastern Brazil. Mem Inst Oswaldo Cruz. 2010; 105(8): 1033-9.

Schönian G, Nasereddin A, Dinse N, Schweynoch C, Schallig HDF, Presber W, et al. PCR diagnosis and characterization of Leishmania in local and imported clinical samples. Diagn Microbiol Infect Dis. 2003; 47(1): 349-58.

Souza CF, Borges MZ, Andrade AJ. Contribution to the knowledge of the phlebotomine sand flies fauna (Diptera: psychodidae) of Timóteo municipality, Minas Gerais, Brazil. Neotrop Entomol. 2009; 38(2): 267-71.

Teodoro U, Thomaz-soccol V, Abbas M, Dias DC. Reorganization and cleanness of peridomiciliar area to control sand flies (Diptera, Psychodidae, Phlebotominae) in South Brazil. Braz Arch Biol Technol. 2004; 47(2): 205-12.

Walters LL, Irons KP, Chaplin G, Tesh RB. Life cycle of Leishmania major (Kinetoplastida: Trypanosomatidae) in the neotropical sand fly Lutzomyia longipalpis (Diptera: Psychodidae). J Med Entomol. 1993; 30(4): 699-718.

WHO - World Health Organization. Control of the leishmaniases. 2010. Available from: http://www.pubmedcentral.nih.gov/articlerender. fcgi artid $=3307017 \&$ tool $=$ pmcentre $\& \&$ rendertype $=$ abstract . 